\title{
The triplets: Investment in outcomes for the vulnerable - reshaping social services for (some) New Zealand children
}

\author{
Michael O’Brien University of Auckland, New Zealand
}

\begin{abstract}
Social work and social services are in a period of significant change built around three key terms; investment, vulnerable, and outcomes. Those terms are not simple neutral descriptors. Rather, they are shaped in critical ways by the neoliberal framework which informs them. The framework is critically examined here by exploring how it is reflected in the specific meanings and implications of each of the three terms. Social work practice and social services delivery will be heavily influenced by the political and ideological framing of investment, vulnerable and outcomes. The paper takes up some of these implications and raises a series of questions for children and families, for practitioners and for agencies. The responses to those questions will be critical for social work and for those with whom and for whom social workers work.
\end{abstract}

KEYWORDS: vulnerable; social investment; outcomes; social work; neoliberal

\section{Introduction}

Change in social services for children and families have been an integral part of the current government's programme for a number of years. This is reflected in a range of government documents and in specific changes such as, for example, the social sector trials and the work around 'vulnerable children' through the Green Paper for Vulnerable Children (2011), the White Paper for Vulnerable Children (2012), the Vulnerable Children Act 2014, and the Children's Teams. These changes have been built around three key terms, namely: (1) investment; (2) outcomes; (3) vulnerable.

Government consistently presents these terms in an unproblematic fashion. That is, they are presented as being an uncontested and uncontestable, part of "common sense." In this process, they reflect many aspects of Harris and White's (2009) four I's - intensification, individualisation, inconvenience and interpellation. After all, who could not be supportive of investing in good outcomes for vulnerable children?

However, an analytic examination of the three terms demonstrates that they are not simple terms of description. They are widely contested and extensively debated in both the literature and practice. Those debates are important in their own right, but, arguably, even more critical in their implications and significance for social work practice and for the role and delivery of social services in Aotearoa New Zealand. The use of the three words in an interconnected fashion highlights their critical ideological and political functions. These functions reflect the neoliberal framework within which the terms are located (Humpage, 2015). They also reinforce that framework through the language which is used and in the application of the terms to social work and social services in Aotearoa New Zealand.

In the discussion that follows, we begin with a necessarily brief summary of the core
AOTEAROA

NEW ZEALAND SOCIAL WORK 28(2), 9-21.

CORRESPONDENCE TO: Michael O'Brien ma.obrien@auckland.ac.nz 
components of the contemporary neoliberal project. With that framework established, we then proceed to an analytic examination of each of the three terms before concluding with a discussion of the consequences and implications for social work and the social services.

\section{Moving on in a neoliberal direction}

Much has been written about neoliberalism and its impacts on social provision over the last three decades; Dean \& Melrose (1999) and Dwyer (2004) provide good examples. (For a useful discussion of neoliberalism's roots and framework, see Cheyne, O'Brien \& Belgrave, 2008; Humpage, 2015; Larner, 2000a; Larner, 2000b). The critical elements for our purposes here are an emphasis on markets, market provision and market solutions; limited (in some instances minimal) government provision; individual, family and charitable provision and the responsibility of individuals for their own wellbeing. Politically and economically, the application of the neoliberal framework in Aotearoa New Zealand has been associated with and led, inter alia, to (1) extensive development of contracting with the private and not for profit sector; (2) far-reaching welfare reforms premised on an emphasis on paid work and (3) privatisation of a wide range of formerly public activities and services. Humpage (2015, p.26, Table 2.2) aptly describes the current phase of neoliberalism as "roll-over neoliberalism", marked in particular by strategic cuts, greater targeting, small government, public asset sales, choice and competitiveness, extension of conditionality and paternalistic views on family and poverty.

The political and economic dimensions of neoliberalism have been accompanied and supported by a range of persistent and consistent ideological messages. These messages have been very important in developing and sustaining ideas and beliefs supporting the economic and political reforms. In particular, they have helped to create and build sets of beliefs and ideas about the causes of "social problems", their nature and possible solutions. Central to these beliefs and ideas have been an emphasis on free choice, the use of markets to deliver services, less or smaller government (including limitation of direct state intervention), lowering of direct taxation, individualising of responsibility for personal and social circumstances.

These overall themes are well reflected in a recent speech by Aotearoa New Zealand's Minister of Finance (English, 2015, June), in which he argued for smaller government, lower government expenditure, individual responsibility and investment expenditure to reduce longer term costs. He described his government's approach as "incremental radicalism" (English, 2015, June).

With this brief background in mind, we can turn now to look at how investment, vulnerability and outcomes are shaped by this approach and some of the implications of this direction for social work and social services. In brief, the triplets are used so as to narrow the public and professional remit and push social work towards a surveillance role, managing the troublesome (not the "troubled" and their "troubles"), with an emphasis on social work's social control functions. This is quite nicely captured in the work of the Expert Panel (Modernising Child Youth and Family Expert Panel, 2015a) where there is a strong focus on children in state care (a narrow group of vulnerable children) but with no attention to either the wider issues for the families of those children (families to which they will almost inevitably return) or to the social and economic circumstances surrounding those families and their communities. Indeed, the focus on rescuing these "vulnerable children" serves to prevent an examination of these wider issues, particularly the issues of child poverty, despite the report acknowledging that poverty and poor housing are substantial issues for a significant proportion of children in care. 


\section{The triplets}

\section{Triplet one: Investment}

While the term "investment" is not unique to the social service reforms, it has formed the framework of both the rationale for and the rhetoric around reform. In his 2015 Menzies Research Centre speech, the New Zealand Minister of Finance described the social investment approach as being: "prepared to spend money now to secure better long-term results for the most vulnerable New Zealanders, and lower costs to the government in the future" (English, 2015, June, para. 94). This echoes his argument in an earlier address to Treasury when he described the approach as follows:

At its core, social investment is a more rigorous and evidence-based feedback loop linking service delivery to a better understanding of people's needs and indicators of the effectiveness of social services...We are willing to invest now to help these most at-risk people lead better lives - and save taxpayers money in the long run. Our goal is to shift from social spending to social investment. Less money on paying benefits or locking people up. More money to invest in social services which improve people's lives in the longterm. (English, 2015, June, para. 43)

The New Zealand Treasury had taken a similar approach in its 2014 briefing to the incoming government when it noted in its discussion on social inclusion that priorities should include:

Expanding smart social sector investment and helping those on the lowest incomes; a continued shift towards investment in effective social sector interventions, that improve long-term outcomes, reduce long-term economic, fiscal and social costs and focus on those most in need (New Zealand Treasury, 2014, p. 2).

A range of government documents take up the idea of investment as determining government expenditure decisions and, therefore, priorities. Overall, these documents have been shaped by the Better Public Services framework (State Services Commission, 2013) with its identification of 10 specific targets for government actions and services, one of which is reducing the number of assaults on children. While the overall investment framework is well set out in Investing in Services for Outcomes (Ministry of Social Development, 2014), the term had been widely used by the Welfare Working Group (2011) in its discussion on social security reforms. "Investment" also provides the framework for the subsequent reports from Taylor Fry and Ministry of Social Development (2016) on the effects of the social security changes.

The 2015 Cabinet paper from the Social Development Minister's office reflects the overall framework when it states:

It [Community Investment Strategy [CIS]] will ensure purchasing for vulnerable people is better targeted at Government priorities and the highest-needs clients, more effective, more transparent and more focussed on results (Ministry of Social Development, 2015b, p. 1).

The Community Investment Strategy is designed to ensure that existing government funding is focused on the most effective services for the most vulnerable priority populations. (Ministry of Social Development, 2015b, p. 3)

Two aspects of these quotations are worth highlighting, namely that the focus is on government expenditure and, within this framework, priority will be given to what government identifies as "priority populations." (There are a number of aspects of this emphasis that warrant extensive discussion but a wide discussion is outside the focus here; I will return to some of those aspects later in the article). The Ministry of Social Development (MSD) in its document on the CIS identified three priority areas as follows: 
Supporting vulnerable children and children in hardship and reducing maltreatment; supporting vulnerable young people, including youth offenders, and reducing youth crime; supporting adult victims/survivors, addressing perpetrators' behaviour and reducing violent crime. (Minister of Social Development, 2015, p. 7)

These areas reflect and are consistent with those set out in Better Public Services, (State Services Commission, 2013), although this document does not specify reducing children in hardship as a target; rather it focuses on reducing the welfare benefit roll.

An actuarially focused investment approach was reflected too in the interim report of the Expert Panel, with the diagram (Modernising Child Youth and Family Expert Panel, 2015a, Figure 8.1, p.106) setting out the framework incorporating the notion of an actuarial approach, while the subsequent discussion starts as follows: "At the centre of the investment approach is an actuarial valuation of the long-term costs to government associated with the poor outcomes of vulnerable children" (Modernising Child Youth and Family Expert Panel, 2015a, p. 106).

The focus is, then, clear. Government will invest in services for those (vulnerable) children and families at highest risk of poor outcomes (the outcomes are discussed more fully below) to improve their lives and reduce long-term expenditure. Expressed this way, it is a goal which is hard to quarrel with and it is in this sense that the ideological nature of the project is most clearly demonstrated. The investment approach is actuarially shaped and driven, and is built around individual characteristics of those at risk of poor outcomes, reflected perhaps most succinctly in the Minister's comment that: "front line workers in the community will know most of their names. We can deal with them one by one" (English, 2015, September, Emphasis added).

The poverty and inequalities that mark these families and their communities is completely ignored and is reduced to individual experiences. Ideologically, the issue is framed in individual, market driven terms. This framing means that the economic and structural forces which create and sustain the poverty and inequalities which shape the lives of those families and communities are ignored. Intervention is based on a narrow targeting (one by one) and there is no challenge to dominant interests and powerful advantages. It is an approach to "investment" based on a neoliberal political and economic framing, a framing which Morel et al. (2011a, Table 1.1, p.12) note is marked by individual responsibility, any jobs and activation.

"Social investment" has been a strong idea in European social policies for almost two decades, emerging from the failure of neoliberalism and the need for a social policy framework which would widen the base for state action. However, it was applied quite differently in different countries and, as commentators have noted (Morel, Palier \& Palme, 2011a; Hemerijck, 2011), it's very vagueness meant that it is useful politically but not so useful analytically.

The breadth of social investment is captured by Morel et al (2011b):

The social investment approach rests on policies that both invest in human capital development ... and that help to make efficient use of human capital..., while fostering greater social inclusion ... Crucial to this new approach is that social policies should be seen as a productive factor, essential to economic development and employment growth. (Morel et al., 2011b, p.2)

This broad frame is marked by social inclusion, quality jobs and a capabilities approach in which the state is an active partner, enhancing citizenship. Significantly, in their overview, Morel et al (2011b) note that, within the social investment framework, the state is seen as a positive contributor, rather than adopting the 
"blame-it-on-the-state" (Hemerijck, 2011, p.55) approach that characterises the neoliberal approach. The broad social investment framework strengthens and reinforces citizenship, albeit in a different frame from the traditional welfare state.

Social investment is seen as contributing to a wide range of social and economic goals, sometimes captured in the notion of "social development". This is in marked contrast to the neoliberal informed Aotearoa New Zealand approach to "investment" or "social investment". The narrow neoliberal approach adopted in the Aotearoa New Zealand changes is reflected in both Predictive Risk Modelling (PRM) (Keddell, 2014) and in the approach to identifying and responding to the vulnerable, discussed more fully below.

Indeed, with very few exceptions, the Aotearoa New Zealand discussion around the term "investment" - in both the work of the Welfare Working Group (2011) and in the discussions on social service reforms - has been about a narrow financial investment. The discussion reflects the roots of the term in financial markets; it is clear and unambiguous market speak. Thus, government invests in those services (and people) from whom it might receive the best return, understood in the sense of lower long term costs rather than direct positive gains, as an investor in the stock market would act. But, it is not "social investment", at least as discussed in the literature. Reflecting its neoliberal roots, the New Zealand approach to investment minimises the role of the state and concentrates on expenditure within a framework of reduced citizenship rights. This is the antithesis of social development.

\section{Triplet two: Vulnerable/vulnerability}

As with the focus on investment, delineating the vulnerable as priority has a strong immediate appeal. Again, who would not want to improve the lives of the vulnerable? However, this begs a number of very important questions both about how "the vulnerable" are identified - who is vulnerable? What constitutes vulnerability and being vulnerable? Furthermore, how are services and programmes for this group to be provided and on what basis?

While the terms vulnerable and vulnerability have been used extensively in government documents about children, the term itself has been defined and described in a very limited, sometimes circuitous, fashion. The assertion that all children should have the chance to thrive, belong and achieve (Ministry of Social Development, 2011), soon became narrowed to a focus on children who were at risk of abuse and/or neglect. The Minister of Social Development initially noted the significance of poverty in the lives of vulnerable children but disqualified this (and other broader social and economic considerations) as a factor in that vulnerability, and as an appropriate consideration in discussions of abuse and neglect (Ministry of Social Development, 2012). Vulnerability became a narrow descriptive category. It captured a core professional and public concern for protecting "the most vulnerable" through political, social and ideological processes which limited state activity to a narrow, protective, rescuing role. while expressing concern and care for this "vulnerable" group.

The Green Paper on Vulnerable Children (Ministry of Development, 2011) referred to a focus on "New Zealand's most vulnerable children" (Foreword). While identifying the importance of all children having a positive childhood (Ministry of Social Development, 2011, p.3), the Green Paper went on to argue that around $15 \%$ of children are vulnerable (Ministry of Social Development, 2011, p.4), highlighting a range of statistics on child offending, truancy, abuse and neglect, witnessing violence etcetera as reflecting this vulnerability. The range of vulnerable factors subsequently became limited to abuse and neglect. The White Paper for Vulnerable Children (Ministry of Social Development, 2012) confirmed and reinforced this narrowing, setting out its scope as focusing on: 
"vulnerable children who have been abused or maltreated, and those at the greatest risk of maltreatment, along with the adults who are endangering them" (p. 4).

Adopting a narrow individual and family focus, the White Paper went on to define vulnerable children in terms of significant harm to their current and future wellbeing, stating:

Environmental factors that influence child vulnerability include not having their basic emotional, physical, social, developmental and/or cultural needs met at home or in their wider community. (Ministry of Social Development, 2012, p.4)

The final step in this project, the Vulnerable Children Act 2014, described vulnerable children as meaning:

Children of the kind or kinds (that may be or, as the case requires, have been and are currently) identified as vulnerable in the setting of Government priorities under section 7. (Vulnerable Children Act 2014, Section 5)

The Vulnerable Children Act then goes on in Section 6 to identify activities which may be undertaken to promote the interests of vulnerable children, while the next section states that: "The responsible Minister may from time to time, after consulting the children's Ministers, set Government priorities for improving the well-being of vulnerable children" (Vulnerable Children Act 2014, section 7). Parts 2 and 3 of the Act focus on the protection of children; although the actions which may be undertaken under the Act are potentially broad, a narrow child protection emphasis is clearly dominant and, as noted, has dominated the discussion of vulnerable children since the publication of the Green Paper (Ministry of Social Development, 2011).

In the same way that "investment" is a contested term with significant social, political and ideological meanings;

"vulnerable" is also used widely, with quite different meanings and implications. The extent of the use of "vulnerable" and "vulnerability" in the social work literature is revealed, for example, in a word search undertaken for this article; use of these two words to locate potential sources in the British Journal of Social Work during the last decade gave 643 references for the former and 325 for the latter. Recent discussion has seen vulnerable used with a range of quite different and, in many respects unrelated, meanings. For example, it has been used recently in relation to the climate change talks (Ritter and Corbett, 2015), older people living on their own and housing developments for vulnerable individuals and families.

Examining its broad and variable usage, Brown (2015) outlines a range of uses of "vulnerable" in the social services and social work literature. She identifies its use: (1) in a natural or innate way; (2) in a universal sense; (3) in a situational (adverse experiences or circumstances) context and (4) to refer to social and material disadvantage. There are, she notes, important links between vulnerability and risk, the latter term having been widely used in the social policy, social service and social work (and other) literature in recent years (Kemshall, Wilkinson \& Baker, 2013; Shlonsky, 2013; Webb, 2006).

Her distinction between vulnerability and risk notes that "vulnerability" carries with it: "heavily camouflaged assumptions about deservingness and 'appropriate' behaviour" (Brown, 2015, p.46). Reflecting the neoliberal approach, classification as 'vulnerable' contains, she notes, ideas that an individual is vulnerable, may be a risk to others and needs to be controlled. The ideological and political implications of defining the issue as one of vulnerability are well captured in her argument that:

This vulnerability-transgression nexus is significant in terms of informing how people are managed and appraised, 
and in shaping which individuals and groups are included and excluded when interventions are organised on the basis of vulnerability. (Brown, 2015, p.46)

"Vulnerable" children and families are identified because they exhibit particular characteristics and/or behaviours.

Furthermore, their identification leads to a focus on managing and supervising "the deviant", an integral part of roll-over neoliberalism. This issue has important ramifications for social work and the social services; I will return to these implications in the conclusion of this article.

Noting that vulnerability is "deeply imbued with ethical and practical implications" (Brown, 2015, p.46), she highlights the ways in which the term can be used in a narrow or broad sense. She argues that the latter leads to development of universal, socially transformative programmes, while the narrow usage "is tied to paternalism and individualism" (Brown, 2015, p.46) which are patronising and stigmatising. It is the narrow sense which has seen the development of data analytics focusing on outcomes for the vulnerable in the New Zealand work on vulnerability. In that work, the emphasis has been on identifying the contemporary version of the "deserving poor" through the use of tools such as PRM (Keddell, 2014). These tools and the surveillance which is inherent in them shift responsibility from the state to the individual, a shift which carries with it an implicit (and sometimes explicit) victim blaming approach.

\section{Triplet three: Outcomes}

As with "investment" and "vulnerable", improving outcomes from social service programmes and practice has been a strong and dominant dimension of government work on social services over the last five years. This is reflected perhaps most directly in the title of the overarching framework, namely "Investment in Outcomes", a title which links together two of the terms focused on in this discussion. Improved outcomes are central too to the focus on "vulnerable children" and to the Better Public Services targets where one of the four action areas in relation to vulnerable children outcomes is: "To do better for vulnerable children, we need to ensure that Government is funding the right services and that these services make a proven difference" (State Services Commission, 2012, p.6).

Similarly, in its briefing to the incoming government in 2014, the New Zealand Treasury highlighted outcomes-based funding as the key to the development of government social spending. Treasury's first principle shaping funding decisions should, they said, be: "clarity on the key measureable outcomes" (New Zealand Treasury, 2014, p.13). The Treasury approach was echoed too in both the Cabinet Paper on the development of a Results Measurement Framework (Minister of Social Development, 2015) and in Investing in Services for Outcomes (Ministry of Social Development, 2015).

Again, in the Draft Community Investment Strategy, the Minister noted that some services which focus on areas of prevention and early intervention would no longer be funded, the Minister stating that:

I intend that within three years all funding will be reaching the communities most in need and will be fully aligned with government priorities. All service contracts will have outcomes focused performance measures, and all unnecessary duplication will be eliminated. (Cabinet Social Policy Committee, 2015, para. 3)

The Minister went on to observe that this was likely to lead to some services being financially unviable.

The outcomes are, as noted, aligned with Better Public Services and with government objectives and priorities - services will be funded to the extent to which they align with 
and support government identified priorities. This is critical. Historically and traditionally, social services have been described as being provided to meet community needs (Cheyne et al., 2008), and those needs were identified, defined and prioritised. The current outcomes approach shifts this considerably; government now determines needs. More precisely, funding must be aligned with government priorities rather than be defined by needs identified by social services agencies, users and/or the community.

What, then, do we know about the experiences and circumstances of "vulnerable" children? In his review of children in state care (Office of the Children's Commissioner, 2015), the Children's Commissioner highlighted abuse of children in care, educational disadvantage, poor health and a higher likelihood of offending among this group. Noting the inadequacy of available data, he commented that:

Many of the children now coming to the attention of CYF are doing so because of chronic long term issues that impact on their safety and wellbeing, for example entrenched family violence, neglect, parents with mental health or alcohol and drug addictions, or children experiencing long term severe poverty and material deprivation. (Office of the Children's Commissioner, 2015, p.31)

The Expert Panel established by the Minister of Social Development to review Child Youth and Family (Modernising Child Youth and Family Expert Panel, 2015a; 2015b) reinforces some of this data, with more specific statistical material not available for the Commissioner for Children's Report. It also notes the backgrounds of children coming into care before the age of five, highlighting, inter alia, long term benefit receipt, much higher likelihood of living in an area of high deprivation, greater likelihood of being in a sole parent family, high mental health needs of mothers, over-representation of Māori, high rates of experiences of family violence (Modernising Child Youth and Family Expert
Panel, 2015a, Figure 4.1, p.33; Figure 4.2, p.35). Significantly, the discussion begins with the following paragraph:

Most of the families of children who are referred to CYF have high levels of longterm need and disadvantage. Many are living in families who are experiencing the combined impacts of long-term unemployment, low income, unaddressed physical and mental health needs, parental alcohol and drug addictions and family violence. Understanding the nature of these underlying circumstances is an essential starting point for understanding how best to respond to child maltreatment and youth offending. (Modernising Child Youth and Family Expert Panel, 2015a, p.32)

Notably the implications of "these underlying circumstances" for the families and for the services are not addressed in the subsequent discussion, and recommendations in either report.

In the reports from both the Office of the Children's Commissioner (2015) and the Expert Panel (Modernising Child Youth and Family Expert Panel, 2015a; 2015b), poverty and material disadvantage are clearly identified as critical for the families with whom Child Youth and Family (CYF) social workers work. Consistent with the neoliberal framing, the focus for the Expert Panel is, however, on individual characteristics such as notification to CYF, imprisonment, educational results and benefit receipt. These outcomes occur disproportionately in households which are below the poverty line and it is this poverty which is critical in the lives of these children and their families, a poverty which the Expert Panel ignores. It is worth noting here that in some of the earlier work on areas of focus for Better Public Services and for vulnerable children, reducing the number of children in hardship (the term that is used by government rather than the word "poverty") was identified as one of the targets. This target disappeared in later versions. 
An integral part of the investment approach to outcomes is the data analytics work. This work was developed initially as part of the Predictive Risk Modelling (PRM) framework applied to child abuse prediction (Vaithianathan, 2012) and has been extended subsequently into a wider focus on children at risk of poor outcomes. In their paper, Crichton, Templeton \& Tumen (2015) argue that their review of the available data illustrates what they describe as the risk factors for children:

The outcomes of children who by age 5 were known to CYF, had a parent or caregiver with a Corrections sentencing history, and had been supported by benefit for most of their childhood, were considerably worse than those of other children. (p.4)

Compared with the total child population born in 1990-91, this group of children, they argue, had worse educational outcomes, higher contact with the youth justice system and with prison, and higher benefit receipt. One percent of the children had three of the risk factors and six percent had two of these factors. As with the focus on "investment" and on "vulnerable", it is, then, "common sense" to look to improve these outcomes. After all, which social worker would argue against better outcomes for these children and their families; change (including improved outcomes) is a fundamental purpose of social work and social service interventions. These children and their whānau need 'investment'. Most of them and their parents and grandparents have not had that investment.

This "commonly shared goal" of improved outcomes provides an important piece of the political and ideological glue to the social investment project, reflecting the directions of the project and the neoliberal framework which drives it. The outcomes are defined and approached in individual terms without attention to the fundamental inequalities, disadvantage, deprivation and poverty which are inherent (and acknowledged) within those outcomes and risk factors. Interestingly and importantly, the New Zealand Treasury (2016) acknowledges that the factors identified in their analysis might in fact be masking more fundamental forces, but investment is not in these more fundamental forces determining vulnerability and outcomes.

Furthermore, there is a critical difficulty with the identification of the outcomes. As the New Zealand Treasury (2016) acknowledges, the relationship between the risk factors and the poor outcomes is mixed and complex. For example, the number of children who experience poor outcomes but do not have the risk factors are greater than the number who have poor outcomes and the risk factors. Second, of those who do have the risk factors, over one-third have none of the poor outcomes (New Zealand Treasury, 2016).

Moreover, the quantitative approach to measuring the outcomes will not provide any information about how those outcomes were achieved. They will tell practitioners, agencies or government if there were fewer people receiving a benefit for a shorter period of time, or whether a larger number are obtaining higher educational results but, by definition, they are unable to provide information about how this happened. Thus, they will not provide any useful or meaningful information for families, agencies or practitioners and will not be able to contribute effectively to the development of better practice.

More fundamentally, however, this approach to outcomes strengthens notions of individual responsibility and a limited role for the state in shaping economic and social objectives. Changing economic and social outcomes needs investment in all citizens, not neoliberal processes of targeting and stigmatising some citizens as deserving based on their share of statistically determined characteristics. Those who succeed will be trumpeted as providing evidence about how "vulnerable" 
backgrounds can be overcome through individual effort, while those who fail will be the subject of blame and greater oversight, management and surveillance.

The next section takes up some of the implications of the preceding discussion for social work and social services.

\section{Concluding reflections: Social work and social service implications}

Why does this matter in terms of delivery of social services and the practice of social work? All three terms - investment, vulnerability, outcomes - are, of course, simple terms which we all understand and which, as noted in this article, make good "common sense". To reiterate, how could anybody in their right mind be opposed to any of the goals and objectives of investment in better outcomes for the vulnerable? The terms have a strong and easy public appeal, especially as they are so frequently repeated, usually without clarification unless it is to reinforce their "obvious" nature and quality. They are in this sense strongly ideological, serving an important political and hegemonic purpose. This purpose is captured succinctly in what Gramsci (1982) has identified as a process of interpellation. By this he means that what are in fact quite contested and politicised terms become taken up in daily language (discourse) as a given, while their essentially contested and political nature is hidden.

"Response to client need" is a central theme in definitions of the role and purpose of social work and social services. Investing in outcomes for vulnerable children reverses that approach; it is not a response to client defined need in that it is neither the families and communities nor the social service agencies and the social workers which identify the need. Rather, it is the government Better Public Services targets which will determine need. In doing so, those targets will significantly shape social services and social work practice because it is alignment with and contribution to these targets which will determine access to government funding. Agencies will still be able to offer services for which they have funding sources other than government funds. However, the pressure on agencies and the government's increasing use of non- government agencies (profit making and not for profit) to deliver services across the total range of government activities will result in many agencies adapting their programmes to reflect the imperatives of funding availability, rather than family, community and their own professional assessment of needs. Neilson, Sedgwick \& Grey (2015) reflect aspects of this when they note that: "government funding and contracting processes are eroding the special characteristics, strengths, and infrastructures of the community and voluntary sector" (p. 9).

Defining and measuring outcomes and the work of the social services and social work in shaping those outcomes is a much more contested and nuanced activity than the narrow focus on "vulnerable children" set out here would suggest. One of the critical considerations in measuring the achievement of outcomes is establishing a causal link between the two activities. In this instance, this means establishing the link between the work of the social worker and of the social services and the specific outcome (result) achieved. It is very easy to confuse correlation (two events happening) and causation (one event resulting in another). Causality, using a quantitative, data analytic tool, requires a specific link to be established between the two events - the action and the result. There are a series of basic requirements in statistical work that need to be met if this causal link is to be established (Bryman, 2012). These include the before and after sequencing, the explicit elimination of other possible linkages (the outcome may result from some other unrelated consideration), and the direction of the link - whether the actions caused the change, or vice versa.

There is a strong reductionist dimension to this data analytic work in that human lives and human experiences are reduced to 
what can be measured. Furthermore, there is another equally critical consideration in reflecting on the emphasis on quantifiably measured outcomes, namely that social work and social service outcomes are often of a qualitative nature and require good qualitative tools to assess the outcomes. These tools do not give the level of statistical precision that quantitative tools provide but they do provide more effective and meaningful measures of outcome that reflect both the work that is undertaken and the aspirations of children, families and communities. It is incumbent on social workers and social service agencies to develop support and utilise good qualitative tools which effectively and meaningfully provide evidence as to effective practice and outcomes.

As increased government control of the work of agencies develops, inevitability in the new framework, social workers and agencies will be faced with critical struggles as they seek to undertake client centred practice. The nature and shape of social work practice and social service delivery will be shaped in significant ways by how we understand investment, vulnerable and outcomes. As the discussion here demonstrates, these are not simple, neutral descriptive words. In the course of practice, a number of critical questions will inevitably arise. I have set some of them out below to attempt to encourage critical reflection.

1. What happens when the government funding no longer continues to support the child and family I am working with, but that family continues to need (and requests) further assistance, but my agency wants me to close the case so that I can take up work with another family that helps to meet the contracting requirements? What does this mean for ideas of client choice, autonomy and professional accountability?

2. How will I deal with government requirements to provide information about clients and their lives?
3. How will I and my agency provide effective social work services when social workers are expected to exercise surveillance on families to ensure they are meeting government established requirements/ behaviours? The welfare reforms have significantly extended surveillance of the poor with a focus on outcomes. "Investing" in "outcomes" for "vulnerable" children and families will lead to social workers being required to undertake greater surveillance, management and oversight of clients - how will we respond to these requirements?

4. How will the work of agencies and of practitioners ensure that practice and the delivery of services are bicultural and multicultural? Much of the focus on protection of children occurs without any meaningful understanding of the critical significance of cultural identity and enhancement of whakapapa. How, then, will we ensure that our practice and the work of our agencies is undertaken in ways which meaningfully honour Treaty obligations and are undertaken in a culturally appropriate manner?

5. The Expert Panel (Modernising Child Youth and Family Expert Panel, 2015a; 2015b) highlights the grossly disproportionate percentage of Māori children in state care. How will practice in the new environment reduce these numbers and be carried out in ways which demonstrate bicultural practice and is consistent with Treaty of Waitangi requirements?

6. How will I deal with agency contracted agreements and/or implicit and explicit messages not to be publically critical of government policy when I know that that policy is harmful to my clients and community? (Note: there is already anecdotal evidence of gagging clauses being written into contracts).

7. What will I do if I discover statistics and services being managed in order to 
show particular outcomes? This might happen through, for example, some form of screening so that services are only provided to those individuals/families who have a good chance of "succeeding", a process known as "cherry picking". (The risks of this happening are specifically referred to by the New Zealand Productivity Commission, 2015).

8. How will I meet my ethical and professional obligations to be an effective advocate for and with clients? If the practice of advocacy and social justice is to continue to be a central part of the ethics of social work (Aotearoa New Zealand Association of Social Workers, 2013), how will we ensure that these remain central in an environment determined by outcomes and investment?

9. Who and what is supported and how is that decided - and in whose interests? In other words, which groups will we work with (or not) and why (or why not)? Who will determine that and on what basis?

With the emphasis on individualisation, an increasingly limited state sector and government prioritisation of needs, there is a fundamental question for the not for profit sector in the new directions, namely what is to be its relationship with the state. Some years ago Nowland-Foreman (1995) talked of the risk of agencies becoming "little fingers of the state" as they increasingly took on work for and on behalf of the state. This risk is widened and deepened through investing in outcomes for the vulnerable and perhaps extends to being hands of the state rather than little fingers!!

\section{References}

Aotearoa New Zealand Association of Social Workers. (2013). Code of Ethics. Christchurch: Aotearoa New Zealand Association of Social Workers.

Brown, K. (2015). Vulnerability and young people: Care and social control in policy and practice. Bristol: Policy Press.

Bryman, A. (2012). Social Research Methods. (4 ${ }^{\text {th }}$ ed.) Oxford: Oxford University Press.
Cabinet Social Policy Committee (2015). Investing in Services for Outcomes: Community Investment Strategy Completion and Sector Engagement. SOC 15(24). Wellington: New Zealand Government.

Cheyne, C., O'Brien, M., \& Belgrave, M. (2008) Social Policy in Aotearoa New Zealand ( $4^{\text {th }}$ ed.). Melbourne, Australia: Oxford University Press.

Crichton, S., Templeton, R., \& Tunmen, S. (2015). Using Integrated Administrative Data to Understand Children at Risk of Poor Outcomes as Young Adults. Wellington: Treasury. Analytical Paper 15/01. Retrieved from http://www.treasury.govt.nz/publications/research-policy/ ap/2015/15-01/ap15-01.pdf

Dean, H., \& Melrose, M. (1999). Poverty, Riches, and Social Citizenship. New York: St Martin Press.

Dwyer, P. (2004). Understanding Social Citizenship. Themes and Perspectives for Policy and Practice. Bristol: Policy Press.

English, B. (2015, September). Speech to the Treasury Guest Lecture Series on Social Investment. Speech presented at Wellington, New Zealand. Retrieved from https://www.beehive.govt.nz/speech/speech-treasuryguest-lecture-series-social-investment

English, B. (2015, June). Annual John Howard Lecture to Menzies Research Centre. Speech presented at Melbourne, Australia. Retrieved from https://www.beehive.govt.nz/speech/annual-johnhoward-lecture-menzies-research-centre

Gramsci, A. (1982). Selections from the prison notebooks. (Q. Hoare \& G. Smith, Eds. \& Trans.). London: Lawrence and Wishart.

Grey, S., \& Sedgwick, C. (2013). The contracted state and constrained democracy. Policy Quarterly, 9(3), 3-10.

Harris, J., \& White, V. (2009). Afterword: Intensification, individualisation, inconvenience, interpellation. In Harris, J., V. White (Eds.). Modernising Social Work (pp. 165-171). Bristol: Policy Press.

Hemerijck, A. (2011). Two or three wave of welfare state transformation? In Morel, N., B. Palier \& J. Palme (Eds.). Towards A Social Investment Welfare State? (pp. 33-60). Bristol: Policy Press.

Humpage, L. (2015). Public Change, Public Attitudes and Social Citizenship. Bristol: Policy Press.

Keddell, E. (2014). The ethics of predictive risk modelling in the Aotearoa/New Zealand welfare context: Child welfare protection or neoliberal tool? Critical Social Policy, 35(1), 69-88.

Kemshall, H., Wilkinson, B., \& Baker, K. (2013). Working with Risk: Skills for contemporary social work. Cambridge: Polity Press.

Larner, W. (2000a). Neo-liberalism: Policy, ideology, governmentality. Studies in Political Economy, 63, 5-25.

Larner, W. (2000b). Post-welfare state governance: Towards a code of social and family responsibility. Social Politics: International Studies in Gender, State and Society, $7(2), 244-265$

Minister of Social Development (2015). Investing in Services for Outcomes: Community Investment Strategy - Completion and Sector Engagement. Wellington, New Zealand: Author. Retrieved from http://www.msd.govt.nz/ documents/about-msd-and-our-work/work-programmes/ 
community-investment-strategy/cis-cab-papercompletion-and-sector-engagement.pdf

Ministry of Social Development (2015). Investing in Services for Outcomes: Community Investment Strategy. Wellington, New Zealand: Author. Retrieved from http://www.msd.govt.nz/about-msd-and-our-work/workprogrammes/community-investment-strategy/

Modernising Child Youth and Family Expert Panel (2015a). Interim Report of the Expert Panel: Modernising Child Youth and Family. Wellington, New Zealand Ministry of Social Development. Retrieved from http://www.msd.govt.nz/documents/about-msd-and-ourwork/work-programmes/cyf-modernisation/interim-reportexpert-panel.pdf

Modernising Child Youth and Family Expert Panel (2015b). Expert panel final report: Investing in New Zealand's children and their families. Wellington, New Zealand: Ministry of Social Development. Retrieved from https://www.msd.govt.nz/documents/about-msd-andourwork/work programmes/investing-in-children/investingin-children-report.pdf

Ministry of Social Development (2014). Investing in Services for Outcomes. Wellington, New Zealand: Author. Retrieved from http://www.msd.govt.nz/about-msd-andour-work/work-programmes/investing-in-services-foroutcomes/

Ministry of Social Development (2012). White Paper for Vulnerable Children: Vol. 1. Wellington, New Zealand: Author.

Ministry of Social Development (2011). Green Paper for Vulnerable Children. Wellington, New Zealand: Author.

Morel, N., Palier, B., \& Palme, J. (2011a). Social investment: a paradigm in search of a new economic model and political mobilisation. In N. Morel, B. Palier, \& J. Palme (Eds.). Towards A Social Investment State? (pp. 353-376). Bristol: Policy Press.

Morel, N., Palier, B., \& Palme, J. (2011b). Beyond the welfare state as we knew it? In N. Morel, B. Palier, \& J. Palme (Eds.). Towards a Social Investment Welfare State? (pp. 1-19). Bristol: Policy Press.

Neilson, B., Sedgwick, C., \& Grey, S. (2015). Outcomes Plus: The added value provided by community social services. Wellington: New Zealand Council of Christian Social Services.

New Zealand Productivity Commission (2015). More effective social services. Wellington, New Zealand: Author. Retrieved from http://www.productivity.govt.nz/sites/ default/files/social-services-final-report-main.pdf

New Zealand Treasury (2016). Characteristics of children at risk. Treasury infographic. Wellington, New Zealand: Author. Retrieved from http://www.treasury.govt.nz/ statesector/socialinvestment/data

New Zealand Treasury (2014). 2014 Briefing to incoming Minister of Finance. Wellington, New Zealand: Author. Retrieved from http://www.treasury.govt.nz/publications/ briefings/2014-priorities/bim-14-priorities.pdf

Nowland-Foreman, G. (1995). Neither mendicants nor dealmakers: Contracting, government funding and voluntary organisations. Wellington, New Zealand: New Zealand Council of Christian Social Services.

Office of the Children's Commissioner (2015a). Giving children the best health care possible: Submission on the update of the New Zealand Health Strategy.
Wellington, New Zealand: Author. Retrieved from http://www.occ.org.nz/assets/Uploads/submissions/RussellWills-Submission-to-Update-of-NZ-Health-Strategy.pdf

Office of the Children's Commissioner (2015b). State of Care2015: What we learnt from monitoring Child, Youth and Family. Wellington, New Zealand: Author. Retrieved from http://www.occ.org.nz/assets/Publications/OCCState-of-Care-2015.pdt

Shlonsky, A. (2013). Risk assessment in child protection services. New York: Oxford University Press.

State Services Commission (2012) New Zealand Government. Delivering Better Public Services, Supporting Vulnerable Children. Result Action Plan. Wellington: State Services Commission. Retrieved from https://www.ssc.govt.nz/bps-cab-papers-minutes

State Services Commission (2013). Better Public Service Results Targets. Wellington, New Zealand: Author. Retrieved from https://www.ssc.govt.nz/bps-supportingvulnerable-children

Ritter, K., \& Corbet, S. (2015, December 11). New draft climate deal emerges as Paris talks near end. New Zealand Herald.

Taylor Fry, \& Ministry of Social Development (2016). Valuation of the Benefit System for Working Age Adults as at June 30, 2015. Wellington, New Zealand Authors. Retrieved from https://www.msd.govt.nz/ documents/about-msd-and-our-work/newsroom/mediareleases/2016/nz-msd-valuation-2015-final-27-jan-2.pdf

Vaithianathan, R. (2012). Can administrative data be used to identify children at risk of adverse outcomes? Auckland, New Zealand: Business School, Department of Economics, University of Auckland.

Vulnerable Children Act. New Zealand Statutes 2014

Webb, S. (2006). Social work in a risk society: Social and political perspectives. New York: Palgrave Macmillan.

Welfare Working Group (2011). Reducing Long Term Benefit Dependency: Recommendations. Wellington, New Zealand: Author. Retrieved from http://igps.victoria.ac.nz/ WelfareWorkingGroup/Index.html 